Vol. 3, No. 05; 2020

ISSN: 2581-4664

\title{
RESEARCH FACTORS AFFECTING THE LOAN DECISION OF INDIVIDUAL CUSTOMERS AT SAIGON JOINT STOCK COMMERCIAL BANK - BINH THANH BRANCH, HO CHI MINH CITY, VIETNAM
}

\author{
Le Quang Khoi ${ }^{1}$, ChauQuang Tuan ${ }^{2}$ and Dang Quoc Viet ${ }^{3}$ \\ ${ }^{1}$ Faculty of Economics - Ho Chi Minh City University of Natural Resources and Environment \\ ${ }^{2}$ Faculty of Economics - Binh Duong University, Vietnam \\ ${ }^{3}$ Faculty of Economics - Binh Duong University, Vietnam \\ http://doi.org/10.35409/IJBMER.2020.3202
}

\begin{abstract}
This study has focused on determining the factors that affect individual customers' loan decisions at SCB BinhThanh Branch. Research data is collected from a survey of 285 individual customers who have borrowed money at SCB BinhThanh Branch. Through Cronbach Alpha testing methods, exploratory factor analysis (EFA), multivariate linear regression analysis, hypothesis and research model testing. The research results have shown that there are 06 important factors that positively affect the loan decision of individual customers at SCB BinhThanh branch arranged in descending order, including: (1) Interest rate, feesof loans $(\beta=0.573)$; Bank brand $(\beta$ $=0.332)$; Loan procedure $(\beta=0.264)$; Service quality $(\beta=0.257) ; 5)$ The form of promotion $(\beta$ $=0.252)$; The influence of relatives $(\beta=0.161)$. On the basis of the research results achieved, a number of suitable managerial implications for the characteristics of SCB BinhThanh branch have been proposed to contribute to continuously improving service quality to maintain existing customers and to earn revenue, attract new individual customers to loan at SCB BinhThanh branch in the next time.
\end{abstract}

Keyword: SCB BinhThanh, loan service, factor analysis.

\section{INTRODUCTION}

Vietnam's global economic integration has brought Vietnamese joint stock commercial banks many opportunities but also challenges. To be able to survive and thrive in today's fiercely competitive environment requires each bank to build an effective business strategy that is consistent with its goals and resources.

Credit growth plays a very important role in the bank's business operations. Credit for individual customers is a product that brings a great source of income for the bank. In order to increase lending credit and attract borrowers, banks have constantly built attractive interest policies, simple and fast loan procedures, and continuously improving service quality, create all favorable conditions for customers to make transactions. Currently, individual customers 'demand for consumer loans in the market is very high, so in order to meet and satisfy customers' needs in the best way, the study of factors influencing decisions borrowing from customers is very urgent. 


\section{International Journal of Business Management and Economic Review}

Vol. 3, No. 05; 2020

ISSN: 2581-4664

Recognizing the importance of the above problem, the authors have chosen the topic "Research on factors influencing individual customers' loan decisions at SCB BinhThanh Branch" The main objective of the study is to identify and measure the influence of factors on individual customers' loan decisions at SCB BinhThanhBranch. On that basis, the authors propose some managerial implications to maintain old customers and increase new customers to loan at SCB BinhThanh Branch in the next time.

\section{THEORETICAL BASIS AND RESEARCH MODEL}

\section{Nterest rates and costs of loan}

According to Yue and Tom (1995), Kennington et al. (1996), Nguyen PhucChanh (2016), interest rate and cost are important factors of the price of loan products. Interest is a special kind of price, it is the price of the right to use the capital for a certain period of time, which the user of the capital must pay to the lender, including the deposit rate, the interest rate for the loan. If interest rates are competitive, reasonable fees will attract customers because these are all personal expenses that must be spent when dealing with banks. Interest rates and costs of loan are the factors that customers are first interested in when deciding to choose a bank to loan.

Hypothesis H1: Interest rates and costsof loanhave the same (+) influence on the loan decisions of individual customers aSCB BinhThanh Branch.

\section{Bank brand}

The research results of Kennington et al. (1996), Yue and Tom (1995) showed that the factor of bank brand name positively affects the decision of individual customers to choose a bank to borrow. The bank is a place where customers trust to deposit assets, is a source of capital, is a place to invest, is a payment intermediary so among the important factors that determine the choice of customers in general as well as individual customers in particular for a bank, the prestige issue is the top priority.

Hypothesis H2: The bank brand has a positive (+) influence on the loan decisions of individual customers at SCB BinhThanh Branch.

\section{Service quality}

Research by Christos C. Frangos et al. (2012), Le DucHuy (2015) showed that service quality has a direct impact on the decision of individual customers to choose a bank to borrow money. The bank's respect for customers from the smallest transactions, or attitude of service to teller staff, credit officers, friendliness, courtesy when serving customers, professional skills and qualifications firmly confident to solve the requirements and handle problems arising from customers. Or about the products and services provided by the bank to satisfy customers, information about loan products are provided by the bank and fully updated to customers, most importantly, the level of security confidentiality and security of information in transactions. Therefore, service quality is an indispensable factor in customers' assessment on choosing a bank to borrow money. 


\section{International Journal of Business Management and Economic Review}

Vol. 3, No. 05; 2020

ISSN: 2581-4664

Hypothesis H3: Service quality has a positive impact (+) on the loan decisions of individual customers at SCB BinhThanh Branch.

\section{Bank convenience}

Research results of Tran KhanhBao (2015), Ho Pham ThanhLan (2015), Le DucHuy (2015) show that the convenience factor of banks is also one of the important factors affecting decisions. Bank selection to borrow capital from individual customers. Convenience in the transaction includes factors such as transaction space, transaction location, transaction location and transaction time. Banks with branch offices and extensive transaction offices located at convenient and easy-to-find locations will be a priority for customers. In addition, the transaction space must be airy, spacious and create a sense of comfort for customers when making transactions. Therefore, banks have an extensive network of transaction offices at convenient locations not only creating convenience for customers to transact, but also creating prestige and trust in the bank's size. like the position in the market.

Hypothesis H4: Bank convenience has a positive effect $(+)$ on the loan decisions of individual customers at SCB BinhThanh Branch.

\section{The form of promotion}

Research results of Pham Thi Tam \& Pham Ngoc Thuy (2010); Hoang ThiAnh Thu (2017); Vo Thi Hue (2013); Huynh Thi Ha (2013); Nguyen Ngoc Duy Phuong - Vu ThiHuong (2018) pointed out that promotion has a positive influence on the loan decision of individual customers. Any bank that has an attractive interest rate, promotion policy will attract a large number of customers to loan at the bank.

Hypothesis H4: The form of promotion has a positive effect $(+)$ on the loan decisions of individual customers at SCB BinhThanh Branch.

\section{Loan procedures}

The research results of Ho Pham ThanhLan (2015) and Luong Trung Ngai (2019) showed that the factor of loan procedures has a positive influence on the loan decision of individual customers. In fact, when the loan procedure is simpler, individual customers have decided to access more loans. Currently, there are many individual customers who think that getting a bank loan is very difficult and complicated. Therefore, the more refined the loan procedure, the more convincing customers to decide to borrow money at the bank.

Hypothesis H5: The loan procedure has a positive (+) influence on the borrowing decisions of individual customers at SCB BinhThanh Branch.

\section{The influence of relatives}

According to Ornella Ricci and Massimo Caratelli (2013) and Le DucHuy (2015), the influence of relatives will affect the choices of customers, friends, relatives, colleagues of organizations and agencies, who used to borrow loans. In a credit institution, those who have used the service at the credit institution, when the customers are introduced by the above subjects before the problems encountered when borrowing loans and recommending the credit institution, they will have a direct impact decision of the customer. Thus, it is easier for customers to make a loan decision at the bank when they are referred by friends, relatives, colleagues, and mass organizations.

Hypothesis H7: Affecting relatives has a positive $(+)$ influence on the loan decisions of individual customers at SCB BinhThanh Branch. 


\section{International Journal of Business Management and Economic Review}

Vol. 3, No. 05; 2020

ISSN: 2581-4664

Based on the theoretical background and previous research results, and based on the characteristics of individual customers at SCB BinhThanh Branch, the author proposes a research model with 6 factors affecting the loan decision at SCB BinhThanh Branch includes: Interest rates and costs of loan; Bank brand; Service quality; The form of promotion; Loan procedures; Convenience; The influence of relatives.

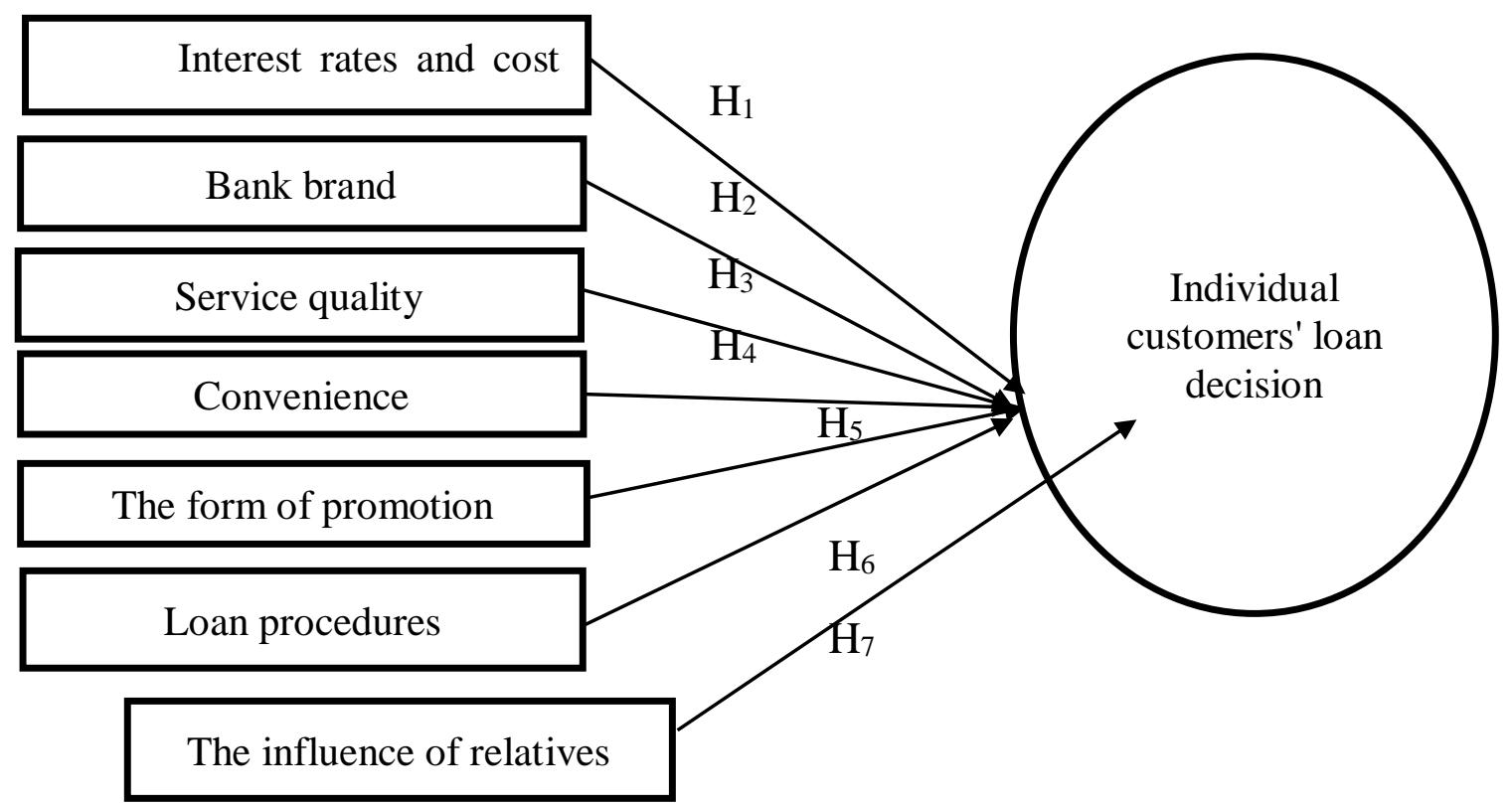

Figure 1. Research model of factors influencing individual customers' loan decision at SCB BinhThanh Branch

2.RESEARCH METHODS

Source: Author compiled, 2020

Research is conducted through two main steps: qualitative research and quantitative research. Qualitative research was conducted by group discussion, in-depth interviews with loan officers and borrowers at SCB BinhThanh Branch. They are people with a lot of knowledge, experience and knowledge in the field of bank loans. The purpose of discussion and in-depth interviews with experts is to help eliminate indicators of ambiguity, duplication of content, and add appropriate words to accurately reflect the content of the research problem. Results of qualitative research, fully determined scales include 07 independent variables with 31 observed variables and 01 dependent variable considered influencing the loan decisions of individual customers at SCB. BinhThanh Branch. The author uses a 5-level Likert scale to measure respondents' consent on statements. 


\section{International Journal of Business Management and Economic Review}

Vol. 3, No. 05; 2020

ISSN: 2581-4664

\section{RESEARCH RESULTS}

\section{Describe the overall sample}

In order to evaluate the factors influencing the decision of individual customers to choose a loan bank at SCB BinhThanh Branch, the authors surveyed 290 customers. Data after the survey collected, encoded, entered and cleaned, the number of valid survey questionnaires met the requirements of 285 questionnaires and 05 questionnaires are not valid. Collected data were processed on statistical software SPSS 20.0.

Evaluate the scale with Cronbach's Alpha confidence coefficient

Table 1. Cronbach's Alpha reliability coefficient

\begin{tabular}{|c|c|c|c|c|}
\hline Observed variables & $\begin{array}{c}\text { Number } \\
\text { of } \\
\text { Observed } \\
\text { variables }\end{array}$ & $\begin{array}{c}\text { Cronbach's } \\
\text { Alpha } \\
\text { coefficient }\end{array}$ & $\begin{array}{c}\text { Cronbach's Alpha } \\
\text { coefficient } \\
\text { component } \\
\text { variable - lowest } \\
\text { total variable }\end{array}$ & $\begin{array}{c}\text { Cronbach's } \\
\text { Alpha } \\
\text { coefficient if } \\
\text { variable is } \\
\text { eliminated }\end{array}$ \\
\hline $\begin{array}{c}\text { Individual customers' loan } \\
\text { decision }\end{array}$ & 4 & 0,776 & 0,551 & $0,703-0,737$ \\
\hline $\begin{array}{c}\text { Interest rates } \\
\text { and costs of loan }\end{array}$ & 4 & 0,767 & 0,557 & $0,702-0,717$ \\
\hline Bank brand & 6 & 0,908 & 0,758 & $0,885-0,899$ \\
\hline Service quality & 5 & 0,839 & 0,600 & $0,795-0,818$ \\
\hline Convenience & 4 & 0,749 & 0,514 & $0,654-0,707$ \\
\hline The form of promotion & 4 & 0,799 & 0,587 & $0,738-0,760$ \\
\hline Loan procedures & 4 & 0,878 & 0,709 & $0,837-0,853$ \\
\hline The influence of relatives & 4 & 0,861 & 0,690 & $0,816-0,831$ \\
\hline
\end{tabular}

Source: Results of survey dataprocessing, 2020 
International Journal of Business Management and Economic Review

Vol. 3, No. 05; 2020

ISSN: 2581-4664

The results of testing the reliability of the scale in Table 1 show that Cronbach'sAlpha coefficients total of 01 dependent variable with 04 observed variables and 07 independent variables with 31 observed variables have the component variable - total lowest variable correlation coefficientis greater than 0.3 , so all are accepted. Thus, all 35 observed variables were used in exploratory factor analysis (EFA).

Exploratory Factor Analysis (EFA)

Table 2. Results of factor analysis to discover independent variables

Rotated Component Matrix ${ }^{\mathrm{a}}$

\begin{tabular}{|c|c|c|c|c|c|c|c|}
\hline & \multicolumn{7}{|c|}{ Component } \\
\hline & 1 & 2 & 3 & 4 & 5 & 6 & 7 \\
\hline TH3 & .858 & & & & & & \\
\hline TH2 & .845 & & & & & & \\
\hline TH1 & .838 & & & & & & \\
\hline TH6 & .831 & & & & & & \\
\hline TH4 & .799 & & & & & & \\
\hline TH5 & .783 & & & & & & \\
\hline CLDV3 & & .812 & & & & & \\
\hline CLDV2 & & .789 & & & & & \\
\hline CLDV1 & & .782 & & & & & \\
\hline CLDV5 & & .761 & & & & & \\
\hline CLDV4 & & .746 & & & & & \\
\hline TTV1 & & & .855 & & & & \\
\hline TTV3 & & & .854 & & & & \\
\hline TTV4 & & & .851 & & & & \\
\hline TTV2 & & & .834 & & & & \\
\hline AHNT2 & & & & .849 & & & \\
\hline AHNT4 & & & & .840 & & & \\
\hline AHNT3 & & & & .828 & & & \\
\hline AHNT1 & & & & .827 & & & \\
\hline CT4 & & & & & .804 & & \\
\hline CT2 & & & & & .794 & & \\
\hline CT1 & & & & & .779 & & \\
\hline CT3 & & & & & .767 & & \\
\hline LS2 & & & & & & .771 & \\
\hline $\begin{array}{l}\text { LS4 } \\
\text { LS } 3\end{array}$ & & & & & & $\begin{array}{l}.761 \\
759\end{array}$ & \\
\hline LS1 & & & & & & .757 & \\
\hline STT3 & & & & & & & .808 \\
\hline
\end{tabular}




\section{International Journal of Business Management and Economic Review}

Vol. 3, No. 05; 2020

ISSN: 2581-4664

\begin{tabular}{|l|l|l|l|l|r|}
\hline \hline STT1 & & & & & .743 \\
STT4 & & & & \\
STT2 & & & & \\
.733 \\
\hline Eigenvalues \\
\hline Extracted variance \\
\hline Bartlett test significance level \\
\hline KMO coefficient
\end{tabular}

Extraction Method: Principal Component Analysis.

Rotation Method: Varimax with Kaiser Normalization.

a. Rotation converged in 5 iterations.

Source: Results of survey dataprocessing, 2020

Analysis results of discovering factors for independent variables in table 2 showed that: KMO coefficient value is 0.805 $>0.5$; Bartlett's test with Sig significance level. $=0,000<0.05$. This shows that the factor analysis ensures reliability and statistical significance. The variance extracted at the value of over $50 \%$ and equal to $64.438 \%$ shows that the factors given by the exploratory factor analysis in the independent variables explained $64.438 \%$ of the variation of the original survey data. The coefficient Eigenvalues represents convergence of the analysis, and this value for the last factor is 1.964> 1 , which shows the high convergence of the factors given by the exploratory factor analysis in the independent variables.

The results were divided into 07 groups as follows:

Group 1 consists of 6 observed variables belonging to the group of factors Banking brand nameincludes TH3 TH2 TH1 TH6 TH4 TH5 is named TH. Group 2 consists of 5 observed variables belonging to the group of factors Quality of service including CLDV3 CLDV2 CLDV1 CLDV5 CLDV4 is named this group QoS. Group 3 consists of 4 observed variables in the group of factors Loan procedure includes TTV1 TTV3 TTV4 TTV2 named this group TTV. Group 4 includes 4 observed variables belonging to the group of factors the influence of relatives, including AHNT2 AHNT4 AHNT3 AHNT1 is named this group AHNT. Group 5 consists of 4 observed variables in the factor group CT4 CT2 CT1 CT3 is named CT3. Group 6 consists of 4 observed variables in the factor group Interest rate and loan fees including LS2 LS4 LS3 LS1 is named LS. Group 7 includes 4 observed variables belonging to the Convenience factor group, including STT3 STT1 STT4 STT2 is named STT.

Table 3. Results of KMO and Bartlett tests of the dependent variable KMO and Bartlett's Test

\begin{tabular}{|ll|r|}
\hline Kaiser-Meyer-Olkin Measure of Sampling & .747 \\
Adequacy. & Approx. Chi-Square & 301.000 \\
Bartlett's Test of & df & 6 \\
Sphericity & Sig. & .000 \\
\hline
\end{tabular}

Source: Results of survey dataprocessing, 2020 


\section{International Journal of Business Management and Economic Review}

Vol. 3, No. 05; 2020

ISSN: 2581-4664

Analysis results of dependent variable EFA has value KMO coefficient is $0.747>0.5$ with significance level Sig. $=0,000<0.05$. This shows that the factor analysis of the dependent variable EFA ensures reliability and statistically significant. With standard Eigenvalue greater than 1 dependent variable is extracted into a factor as follows

Table 4. Results of factor analysis EFA dependent variable

\begin{tabular}{|c|c|}
\hline Observed variable & Factor load factor \\
\hline QD3 & .799 \\
\hline QD4 & .784 \\
\hline QD1 & .759 \\
\hline QD2 & .752 \\
\hline Extracted variance (\%) & 59.867 \\
\hline Eigenvalues & 2,395 \\
\hline
\end{tabular}

Source: Results of survey dataprocessing, 2020

The extracted variance is over 50\%, and equal to 59.867\%, showing that the factor given by the exploratory factor analysis in the dependent variable explained $59.867 \%$ of the variation of the original survey data. Eigenvalues coefficients represent convergence of the analysis, and this value is $2.395>1$, which shows the high convergence of factors given by exploratory factor analysis in the dependent variable. The results show that the dependent variable - Loan decision has 4 observed variables named this group as QD.

\section{Pearson correlation coefficient analysis}

Table 5. Pearson coefficient of correlation among variables

\begin{tabular}{|c|c|c|c|c|c|c|c|c|c|}
\hline & & $\overline{\mathrm{QD}}$ & LS & $\mathrm{TH}$ & CLDV & $\begin{array}{l}\text { STT } \\
\end{array}$ & $\overline{C T}$ & TTV & AHNT \\
\hline \multirow{3}{*}{ QD } & Pearson & 1 & $.573^{* * *}$ & $.322_{*}^{*}$ & .257 & $.017^{* * *}$ & $.264^{* * *}$ & .252 & $.161^{* *}$ \\
\hline & $\mathrm{Sig}$ & & .000 & .000 & .000 & .773 & . .000. & .000 & 007 \\
\hline & $\mathrm{N}$ & 285 & 285 & 285 & 285 & 285 & 285 & 285 & 285 \\
\hline \multirow{3}{*}{ LS } & Pearson & $.573^{*}$ & 1 & .000 & $.000^{* * *}$ & .000 & .000 & $.000^{* *}$ & .000 \\
\hline & $\begin{array}{l}\text { Correlat } \\
\text { Sig (2-t }\end{array}$ & 000 & & 1000 & 1000 & 1000 & 1000 & 1000 & 1000 \\
\hline & $\mathrm{N}$ & 285 & 285 & 285 & 285 & 285 & 285 & 285 & 285 \\
\hline \multirow{3}{*}{$\mathrm{TH}$} & Pearson & $.322^{*}$ & .000 & 1 & $.000^{* * *}$ & .000 & .000 & $.000^{* *}$ & .000 \\
\hline & Sig. (2-tailed) & .000 & 1.000 & & 1.000 & 1.000 & 1.000 & 1.000 & 1.000 \\
\hline & $\mathrm{N}$ & 285 & 285 & 285 & 285 & 285 & 285 & 285 & 285 \\
\hline \multirow{3}{*}{ CLDV } & Pearson & $.257^{*}$ & .000 & .000 & $1^{* *}$ & .000 & .000 & $.000^{* * *}$ & .000 \\
\hline & Sig. (2-tailed) & .000 & 1.000 & 1.000 & & 1.000 & 1.000 & 1.000 & 1.000 \\
\hline & $\mathrm{N}$ & 285 & 285 & 285 & 285 & 285 & 285 & 285 & 285 \\
\hline
\end{tabular}




\section{International Journal of Business Management and Economic Review}

Vol. 3, No. 05; 2020

ISSN: 2581-4664

\begin{tabular}{|c|c|c|c|c|c|c|c|c|c|}
\hline \multirow[b]{2}{*}{ STT } & rson & 017 & .000 & .000 & .000 & 1 & .000 & .000 & .000 \\
\hline & Sig. (2-tailed) & .773 & 1.000 & 1.000 & 1.000 & & 1.000 & 1.000 & 1.000 \\
\hline & $\mathrm{N}$ & 285 & 285 & 285 & 285 & 285 & 285 & 285 & 285 \\
\hline \multirow{3}{*}{ CT } & $\begin{array}{l}\text { Pears } \\
\text { Corre }\end{array}$ & $.264^{*}$ & .000 & .000 & $.000^{* *}$ & .000 & 1 & $.000^{* *}$ & .000 \\
\hline & Sig. (2-tailed) & .000 & 1.000 & 1.000 & 1.000 & 1.000 & & 1.000 & 1.000 \\
\hline & $\mathrm{N}$ & 285 & 285 & 285 & 285 & 285 & 285 & 285 & 285 \\
\hline \multirow{2}{*}{ TT } & $\begin{array}{l}\text { Pears } \\
\text { Corre }\end{array}$ & $.252^{*}$ & .000 & .000 & $.000^{* *}$ & .000 & .000 & $1^{* *}$ & .000 \\
\hline & Sig. (2-tailed) & .000 & 1.000 & 1.000 & 1.000 & 1.000 & 1.000 & & 1.000 \\
\hline & $\mathrm{N}$ & 285 & 285 & 285 & 285 & 285 & 285 & 285 & 285 \\
\hline \multirow{3}{*}{ AHNT } & $\begin{array}{l}\text { Pearson } \\
\text { Correlation }\end{array}$ & $.161^{*}$ & .000 & .000 & $.000^{* *}$ & .000 & .000 & $.000^{* * *}$ & 1 \\
\hline & Sig. (2-tailed) & .007 & 1.000 & 1.000 & 1.000 & 1.000 & 1.000 & 1.000 & \\
\hline & $\mathrm{N}$ & 285 & 285 & 285 & 285 & 285 & 285 & 285 & 285 \\
\hline
\end{tabular}

Source: Results of survey data processing, 2020

The results of Pearson correlation analysis in Table 5 show that there are 06 independent variables namely interest rate and costs of loan; Bank brand; Service quality; The form of promotion; Loan procedures; The influence of relatives has sig $=0.00<0.05$, so the authors can say that these 6 independent variables have a linear correlation with the dependent variable and the independent variable, convenience value sig $=0.773>0.05$ does not meet the condition that is, there is no linear correlation relationship with the dependent variable. One of the necessary conditions for regression analysis is that the independent variable must be correlated with the dependent variable, so if in this step of correlation analysis the independent variable has no correlation with the dependent variable, then we remove the independent variable. This out of regression analysis. Therefore, in this study, the author will continue to include 06 eligible independent variables in linear regression analysis.

\section{Verifying the suitability of the model}

Table 6. Model Summary

Model Summary ${ }^{\mathrm{b}}$

\begin{tabular}{|l|r|r|r|r|c|}
\hline Model & R & R Square & $\begin{array}{c}\text { Adjusted R } \\
\text { Square }\end{array}$ & $\begin{array}{l}\text { Std. Error of } \\
\text { the Estimate }\end{array}$ & $\begin{array}{l}\text { Durbin- } \\
\text { Watson }\end{array}$ \\
\hline 1 & $.811^{\mathrm{a}}$ & .657 & .650 & .59166066 & 2.007 \\
\hline
\end{tabular}

a. Predictors: (Constant), REGR factor score 7 for analysis 2, REGR

factor score 6 for analysis 2, REGR factor score 5 for analysis 2, REGR

factor score 3 for analysis 2, REGR factor score 2 for analysis 2, REGR

factor score 1 for analysis 2

b. Dependent Variable: REGR factor score 1 for analysis 1

Source: Results of survey data processing, 2020 
International Journal of Business Management and Economic Review

Vol. 3, No. 05; 2020

ISSN: 2581-4664

Table 7. ANOVA a analytical results

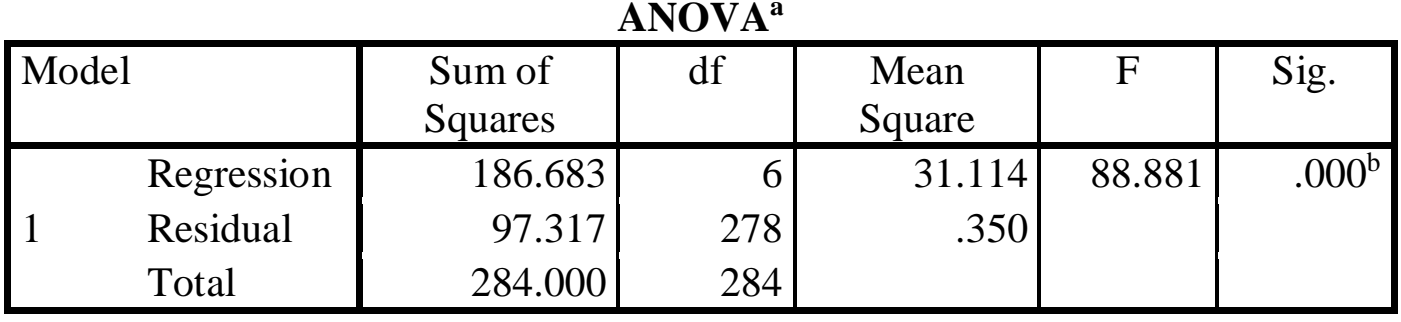

a. Dependent Variable: REGR factor score 1 for analysis 1

b. Predictors: (Constant), REGR factor score 7 for analysis 2, REGR factor score 6 for analysis 2, REGR factor score 5 for analysis 2, REGR factor score 3 for analysis 2, REGR factor score 2 for analysis 2, REGR factor score 1 for analysis 2

Source: Results of survey data processing, 2020

Determination coefficient R2 (Adjusted R Square) $=0.650$, which means that $65 \%$ of the change in choice of loans at SCB BinhThanh branch is explained by independent variables included in the regression model in the study. In this study, the remaining percentage is due to other factors not included in the research model and random error. The Durbin-Watson coefficient of the model is 2.007 , which is almost equal to 2 this shows that there is no correlation phenomenon between the independent variables in the regression model. In ANOVA analysis in Table 7, the value of Sig. $=0,000<0.05$. So the ANOVA analysis results ensure statistical significance, from which the results of regression analysis ensure reliability. The VIF magnification coefficients of the variables in the model are all less than 2 . Therefore, there is no multicollinearity phenomenon in the model.

\section{Regression analysis results}

Table 8. Summary of regression coefficients

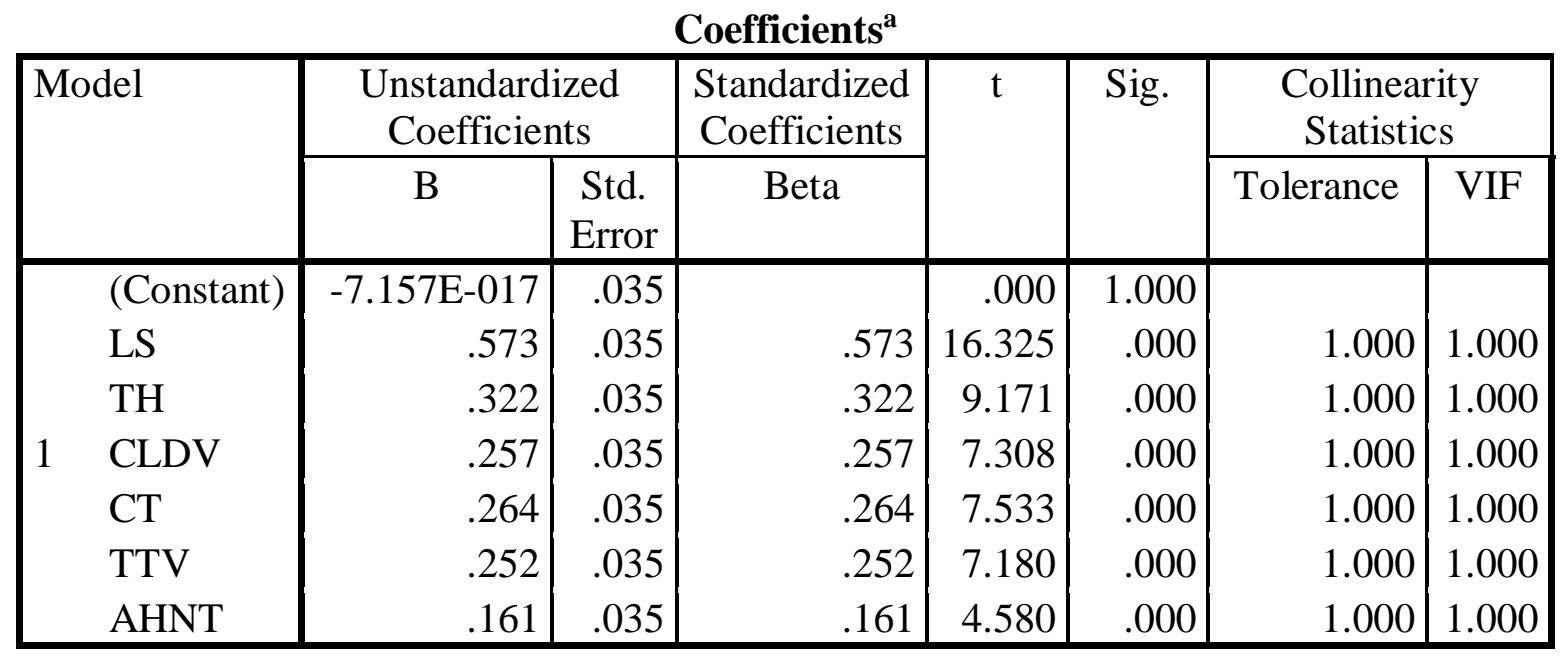




\section{International Journal of Business Management and Economic Review}

Vol. 3, No. 05; 2020

ISSN: 2581-4664

\section{a. Dependent Variable: REGR factor score 1 for analysis 1}

Source: Results of survey data processing, 2020

The results of multiple regression analysis in Table 8 showed that 06 variables (LS, TH, QoS, CT, TTV, AHNT) had Sig. $=0.00<0.05$, so these 6 variables are statistically significant and these 6 variables all have a positive influence with the loan decision at SCB BinhThanh Branch. Thus, the standardized linear regression equation has the following form:

$$
\mathrm{QD}=0,573 * \mathrm{LS}+0,322 * \mathrm{TH}+0,257 * \mathrm{CLDV}+0,264 * \mathrm{CT}+0,252 * \mathrm{TTV}+0,161 * \mathrm{AHNT}
$$

\section{CONCLUSIONS AND MANAGERIAL IMPLICATIONS}

\section{Conclusions}

This study has focused on determining the factors that affect individual customers' loan decisions at SCB BinhThanh Branch. Based on the theory and previous studies related to the research topic, the author proposes a research model and at the same time develops the scale on the conceptual basis and scale of the previous studies. In which, the decision to choose a bank to borrow capital includes 07 factors: (1) Interest rate and costs of loan (LS) is measured by 4 observed variables; Bank brand $(\mathrm{TH})$ is measured by 06 observed variables; Quality of service (CLDV) is measured by 05 observed variables; Convenience (STT) is measured by 4 observed variables; Marketing form (CT) is measured by 4 observed variables; Loan procedure (TTV) is measured by 04 observed variables; The influence of relatives (AHNT) is measured by 04 observed variables. Research data is collected from surveying 290 individual customers who have loaned at SCB BinhThanh Branch according to convenient sampling method. The result of collecting the correct and complete survey questionnaires was 285 . The collected data were processed on the statistical software SPSS 20.0. Through the Cronbach Alpha test methods, exploratory factor analysis (EFA), multivariate linear regression analysis, hypothesis testing and research model,the research results have shown that there are 06 important factors that positively affect the loan decision of individual customers at SCB BinhThanh Branch arranged in descending order, including: (1) Interest rate, feesof loans $(\beta=0.573)$; Bank brand $(\beta=0.332)$; Loan procedure $(\beta=0.264)$; Service quality $(\beta=0.257) ; 5)$ The form of promotion $(\beta=0.252)$; The influence of relatives $(\beta=0.161)$. On the basis of the research results achieved, a number of suitable managerial implications for the characteristics of SCB BinhThanh Branch have been proposed to contribute to continuously improving service quality to maintain existing customers and to earn revenue, attract new individual customers to loan at SCB BinhThanh Branch in the next time.

\section{Managerial implications}

\section{Interest rate and costs of loan}

Interest rate and costs of loanare the factors that have the strongest impact on individual customers' loan decisions compared to other factors at SCB BinhThanh Branch with a standardized Beta coefficient of 0.573. Therefore, SCB BinhThanh Branch needs to pay special attention to this factor. Low interest rates and loan costs are competitive advantages in the market in keeping existing customers and attracting new customers. Based on the deposit interest 


\section{International Journal of Business Management and Economic Review}

Vol. 3, No. 05; 2020

ISSN: 2581-4664

rate, the bank's operating costs to set a more appropriate loan interest rate schedule than by all means to collect customers. The Bank also needs to collect information about the lending rates of the banks that are competitors, in order to offer appropriate interest rates and lending fees and compete in the market. At the same time, it is necessary to closely monitor the fluctuation of lending interest rates in the market to be able to come up with a strategy to respond to loan interest rates quickly and promptly to retain existing customers as well as attract new customers.

\section{Bank brand}

The bank brand is the second most influential factor in the decision to choose a bank to loan from individual customers compared to other factors at SCB BinhThanh Branch with a standardized Beta coefficient of 0.332 . The bank's brand name is very important, contributing to attracting customers to transact. In addition to the historical factors of formation and development, the bank's reputation is growing and making many people known, branch leaders need to have brand development policies of the Bank, in order to strengthen try to trust and improve the reputation of customers when making transactions. In the immediate future, SCB BinhThanh Branch continues to build and maintain the image of a good SCB brand name in the hearts of customers, implementing the unified image to easily recognize the BIDV brand from staff uniforms, interior decoration. transaction places, forms, instruction boards, leaflets, office designs, transaction offices, ATMs ... Focusing on arranging staff with professional qualifications, experience and good consulting skills when delivering communicate with customers, and at the same time pay attention to the staff's behavior and attitude when dealing with customers. In addition, it is necessary to regularly improve and improve service quality through customer feedback.

\section{Service quality}

The quality of banking services has the fourth strongest impact on individual customers' borrowing decisions compared to other factors at SCB BinhThanh Branch with a standardized Beta coefficient of 0.465. Therefore, in the coming time, SCB BinhThanh Branch needs to pay special attention to this factor. In the loan strategy of individual customers, SCB BinhThanh Branch needs to focus on service quality because service quality can help SCB BinhThanh Branch build a new image and make a difference and improve competitive advantage in the market. In order for this to be effective, SCB BinhThanh Branch first needs to promote modern banking services in order to provide customers with information as quickly as possible. Customers can perform their transactions right at work through applications on the phone or online on the web and computer. At the same time, focusing on data quality and security and safety of technology systems, avoiding delays in service delivery to customers, especially paying attention to transmission errors, congestion due to Overload. On the other hand, SCB BinhThanh Branch needs to improve technology by increasing the use of modern technology features that they own and regularly upgrading the technology system according to development trends. stop of information science and technology. Modernize the communication system so that customers can easily contact the bank.

\section{The form of promotion}

According to the survey results of customers, the factor "The form of promotion" is the factor that has the fourth largest influence on customers' loan decisions. Not denying the role of the promotion, helping many customers to know about new products that are attractive from existing 


\section{International Journal of Business Management and Economic Review}

Vol. 3, No. 05; 2020

ISSN: 2581-4664

products, so SCB BinhThanh Branch needs to promote marketing, promoting the brand through the installation of advertising signs, actively participating in sponsoring events, contributing to the community in social work (building gratitude houses, awarding scholarships, etc.) .) contribute to promoting the reputation and brand of the bank. SCB BinhThanh Branch should widely introduce new products to customers or accelerate the role of existing products. In addition to the promotions already available according to events, holidays, birthdays, SCB BinhThanh Branch needs to promote more thanks to its brand characteristics, harmoniously combined with the diversity of banking products, categorize according to each group of customers so that from the common to the unique of the bank in order to create promotional products that attract customers' attention.

\section{Loan procedures}

The next factor affecting the individual customers' loan decision is the loan procedure. The loan procedure, the simpler and clearer the loan terms are, the easier it is for customers to access a bank to get a loan. Because the majority of individual business borrowers face many difficulties related to lack of collateral, poor financial information, lack of business plan or business plan is not really clear, can. Therefore, in order to create favorable conditions for customers to access banks to get loans, SCB BinhThanh Branch needs to improve loan procedures towards simplicity, compactness, and full provision of information about loan products, the necessary conditions to borrow capital and suitable with the individual borrowers' qualifications, avoiding the situation of individual customers having to travel many times and waiting too long. In addition, bank employees need to provide specific instructions, clearly and in detail the loan procedures that individual customers need to have when getting loans, as well as explain clearly to customers about the loan procedures, regulations or terms in the loan agreement, mortgage contract to avoid the situation that customers do not understand or understand, leading to complaints or dissatisfaction with service staff.

\section{Influence of relatives}

Influence of relatives is the factor that has the sixth largest influence on customers' loan decisions at SCB BinhThanh Branch with a standardized Beta coefficient of $\beta=0.161$. This is also a very important factor that SCB BinhThanh Branch needs to pay attention to. In today's era, with the strong development of the financial market, the competition among banks has become more and more fierce. Customers are always interested by many banks, always send open letters to introduce products, promising the best incentives. Because of that, keeping old customers and developing new ones is an extremely important and vital task for each bank. One of the most effective solutions for banks to retain old customers and attract new customers is to create close relationships with customers. A bank that has a good relationship with a customer will have more new customers from the recommendation of old customers who are already using its products and services. Maintaining a good relationship with a former customer is one of a bank's most important tasks as the cost of finding a new customer far outweighs the cost of maintaining one. When a bank gets a new customer, to assess whether the new customer is loyal to the bank or not, the bank takes time to verify it. May help the bank find more new customers through the introduction without any cost. In order to maintain old customers, SCB BinhThanh Branch needs to give priority to service, care and incentives in terms of interest rates of loan terms as well as reducing unnecessary procedures to help customers, comfortable, trustworthy and attached to the bank. 


\section{International Journal of Business Management and Economic Review}

Vol. 3, No. 05; 2020

ISSN: 2581-4664

\section{REFERENCES}

1. Hoang Trong and Chu Nguyen Mong Ngoc, 2008. Research data analysis with SPSS, Hong Duc Publishing House.

2. Ho Pham ThanhLan, 2015. Analysis of factors affecting the individual customers' loan decision at EXIMBANK Can Tho, Master thesis of business administration, Can Tho University.

3. Le DucHuy, 2015. Factors affecting the decision of individual customers to borrow capital at Vietnam Joint Stock Commercial Bank in Ho Chi Minh City, Master Thesis of Finance Banking, Truong Dai Economic School HCMC.

4. Luong Trung Ngai, 2019. Factors influencing the decision of individual customers to borrow money at the Joint Stock Commercial Bank for Investment and Development of Vietnam - TraVinh branch, Master Thesis in Economics, Western University Dollar.

5. Quan Minh Nhut and Huynh Van Tung, 2015. Factors affecting the use of housing credit in Can Tho City. Journal of Economics and Forecasting, 5, 89-91.

6. Tran KhanhBao, 2015. Factors influencing the decision to get a loan at Vietnam Joint Stock Commercial Bank for Industry and Trade of Ho Chi Minh City, Master Thesis of Business Administration, University Economic School HCMC.

7. Ajzen I. (1988), Attitude, Personality and Behavior, Chicago: Dorsey Press

8. Ajzen, I., 1991. The theory of planned behavior, Organizational Behavior and Human Decision Processes, Vol. 50, No.2, pp. 179-211.

9. Carolyn Kennington, Jeanne Hill, Anna Rakowska, (1996),"Consumer selection criteria for banks in Poland", International Journal of Bank Marketing, Vol. 14 Iss 4 pp. 12 - 21.

10. Davis, F. D., Bagozzi, R. P., \&Warshaw, P. R., 1989. User acceptance of computer technology: A comparison of two theoretical models. Management Science, 35: 9821003.

11. Hafeez Ur Rehman and Ahmed, 2008. An Empirical analysis of the determinants of Banks Selection in Pakitstan: A customer view, Pakitstan Economic and Social Review, Volume 46, No.2 (Winter 2008), pp. 147-160.

12. Journal of Marketing Research and Case Studies, 2012. Factors Affecting Customers' Decision for Taking out Bank Loans: A Case of Greek Customers.

13. Martin OwusuAnsa, 2014. An Empirical study on theDeterminnants of Banks Selection in Ghana: Application of principal Factor Annalysison Senior High School Teachers in the Kumasi metropolis, International journal of Academic Research in Business and Social Sciences, July 2014, Vol 4. No. 7, ISSN: 222-6990.

14. PananLeelapongprasut et al, 2005. A Quality Study of Internet Banking in Thailand. Fourth International Conference on eBusiness, November 19-20, 2005, Bangkok, Thailand.

15. Ricci Ornella and Caratelli Massimo, 2013. Consumer Choice in Retail Banking: Are Prices Really Relevant? SSRN Electronic Journal, January 2013.

16. SchiffmanvàKanuk, 1987.Consumer behavior, Prentice - Hall International Editions, 3rd ed, 1987.

17. Ricci Ornella and Caratelli Massimo, 2013. Consumer Choice in Retail Banking: Are Prices Really Relevant? SSRN Electronic Journal, January 2013.

18. Yue, H. and G. Tom., 1995. How the Chinese select their banks. Journal of Retail Banking, Volume XVI, No. 4 (Winter). 
International Journal of Business Management and Economic Review

Vol. 3, No. 05; 2020

ISSN: 2581-4664

19. SchiffmanvàKanuk, 1987.Consumer behavior, Prentice - Hall International Editions, 3rd ed, 1987

20. Taylor Shirley. \& Todd Peter, 1995. Decomposition and crossover effects in the theory of planned behavior: A study of consumer adoption intentions. International Journal of Research in Marketing,12:137-156. 